\title{
Experiential value mediates relationship between Experiential Marketing and Customer Satisfaction
}

\author{
Irfan Ali Shah ${ }^{1 *}$, Zulfiqar Ali Rajper ${ }^{2}$, Ikhtiar Ali Ghumro ${ }^{3}$, Saqib Wahab \\ Mahar $^{4}$
}

\begin{abstract}
This empirical study explores mediating role of experiential value between experiential marketing and Customer satisfaction in the context of Pakistan. The Experiential marketing is used as independent variable consisting of five dimensions (Sense Experience, Feel Experience, Think Experience, Act Experience and Relate Experience), Experiential value is used as mediator which consists of four dimensions- aesthetic, playfulness, service excellence, and consumer return on investment (CROI) Customer Satisfaction is used as dependent variable in this study. Fast food industry is selected in current study. Survey method is used to collect data, SPSS (18) and AMOS (18) versions are used for data analysis. Results are supporting the hypothesis that experiential value mediates relationship between experiential marketing and customer satisfaction. This particular research work is among few relevant studies in which the mediating role explored among the experiential value between experiential marketing and customer satisfaction. The current study will benefit marketers in understanding the importance of customer's experiences, experiential value that leads to Customer Satisfaction.
\end{abstract}

Keywords: Experiential value, experiential marketing, Customer experience, Customer satisfaction

\section{Introduction}

As we are living in the experience economy, nowadays many companies are focusing on creating valuable and memorable experiences with customers. Experiential marketing is new field of marketing which focuses on customer experience while using or interacting with goods and services. Traditional marketing focuses on products features benefits and promotions but nowadays good experiences of customers with product or service are the focus of marketing. Creating valuables experiences for the

${ }^{1}$ Sukkur IBA University

${ }^{2}$ Department of Commerce, SALU Shikarpur Campus

${ }^{3}$ Department of Commerce, Shah Abdul Latif University, Khairpur

${ }^{4}$ Department of Business Administration, SALU Shikarpur Campus

*Corresponding Author: irfanalishah.ms@iba-suk.edu.pk, 
customers is new challenge for marketers. Pine and Gilmore (1998), described the evolution of economic offering and made clarification about his development, in the first stage the classification about the necessity of commodities. In the second stage, which is called the product stage, the companies starting further processes to convert those commodities into finished goods. In the third stage, the goods are combined, which is comprised of tangible products and intangible services known as service stage. The experiential stage is the last stage following the development of the services. So firms in the twenty- first century focus on experience based economy as compared to service based economy (Kim, Cha, Knutson, \& Beck, 2011).

In the field of marketing, experiential marketing is not only emphasis on product or its services but also emphasize that how company acquires the entire experience about their services to create its' customers. The main purpose of current study is to observe relationship among experiential marketing, experiential value and customer satisfaction in fast food restaurants in Pakistan. The current research work is among a few studies which explored mediating role of experiential value between experiential marketing and customer satisfaction. Especially in the context of Pakistan such type of study is not conducted. In previous studies effect of each experiential marketing dimension is separately tested on the outcome variables. But in this research effect of experiential marketing dimensions is simultaneously checked with the help of Structural equation modeling. Nowadays fast food demand is increasing due to change in income, taste, life style and social trends in Pakistan. In the past restaurants were considered only the place where people came to eat meal. But now people visit restaurants not only to eat meal but for the attractive environment, where they may feel comfort and have memorable experience. The factors that influence customer experience, experiential value and customer satisfaction in fast food restaurants include food quality and Price, staff service and physical environment. Nowadays instead of advertising, packing, promotion customer satisfaction depends on experiences that customer gets while using product or interacting with services. To create memorable experiences for the customers is new emerging challenging for the marketers, Products of hospitality and tourism industry are always experiential (Williams, 2006). For example, people go to restaurants not only to eat food but also for the enjoyment, rest and for a good environment. (Y. H. E. Yuan \& C. K. Wu, 2008).

As Douglas and Craig (2011) have included Pakistan into next 11 best markets for multinational corporations (MNCs) having Population of 175 million and GDP 167 billion dollars, so Pakistan is best market for the foreign and local investors., as Pakistan is included among the countries having high rates in the collectivism index. It means in Pakistan group decision is made and word and mouth has much influence on buying decision process. So focusing on memorable experiences will not only retain existing customers but will attract new customers. Demand of fast food restaurants is increasing day by day, fast food restaurants have a long history fast food industry grew rapidly

Sukkur IBA Journal of Management and Business - SIJMB | Volume 5 No. 2 July - December 2018 @) Sukkur IBA University 
after 1970. Customers started to go there and a large number of fast food restaurants was opened like Pizza Hutt, Mc Donald, Burger King, Hamburger. In Pakistan, people visit Fast food restaurantS as an amusement activity

\section{Literature Review}

\section{Experiential marketing}

Experiential marketing is the emerging field of marketing that focuses on customer experiences with products and services, traditional marketing focuses on benefits and features of product or service, but Experiential marketing focuses on memorable experiences that a customer have for product or service. Schmitt (1999), described that the experiential marketing is about the customers perception about the company, after purchasing the goods or services. The customers' perception and experience activities may start after acquiring goods or services. Customer good experiences with product or services stimulate him to repurchase a product or service. Many studies show that brand name, word and mouth, price and advertising impacts on customer experiences (Ismail, 2011), customer experience is a combination of interaction of customer with product or service that incite a reaction (Verhoef et al., 2009).

Main theme of Experiential marketing is Extracting importance of product or service and then converting them into physical, intangible, memorable experiences that enhance the scope of product or service and support customers in buying decision process. (Williams, 2006).Companies not only offers products but good memories and experiences (Y. H. E. Yuan \& C. K. Wu, 2008). Companies should offer customers successful experiences to get competitive advantage and customer satisfaction (VilaLópez \& Rodríguez-Molina, 2013). Traditional marketing considers customers as a rational decision maker who only think about functional features and benefits of product while experiential marketing considers consumers as rational and emotional human beings who are conscious regarding delight experiences (Schmitt, 1999). Brand experience has attracted a lot of attention of the marketers, because brand experience is very important in developing marketing strategies (Brakus, Schmitt, \& Zarantonello, 2009).

\section{Dimensions of Experiential Marketing}

\section{Sense Experience}

The five senses like the sight, smell, sound, touch and taste construct a sensory experience. These five senses may create a sensory experience to motivate customers, the sense marketing may affect by these sensory experience. (Schmitt, 1999), discussed that sense experience is important in bringing the change in the mind of customers about the goods or services. Sense marketing construct a value of product or service in mind

Sukkur IBA Journal of Management and Business - SIJMB | Volume 5 No. 2 July - December 2018 @ Sukkur IBA University 
of customer, it develops cognitive, behavioral, logical, emotional and relational approach towards the product or service. It helps create a sensory experience about the company's product or service.

\section{Feel Experience}

The emotions and moods are concerned with internal feelings: feel experiences comprise the inner emotions and moods. The effective experience may cause with the object of such emotions and moods (Schmitt, 1999) the relation with product or service creates effective feelings. The strong feelings come after the consumptions of product over the period of time.

\section{Think Experience}

Schmitt (1999), described that think experience aimed to encourage the customer to think about the product or service. It is a creative and theoretical practice in which the customers are involved to create cognitive experience towards the product or service. The purpose of think experience is to involve the customers to get the feedback for product or service

\section{Act Experience}

Schmitt (1999), described that customers improve their act experience by using products physically so their tangible experience guided them by having alternative contacts and the different ways of life style. The act experience helps the customers by having a physical experience towards the product, that is related with behavior and life style, the behavioral pattern and the life style of the customers can be improved by tangible experience. The act experience holds a positive impression to change the behavior of customers in long term in purchase intention towards the company's product or service. Act experience helps the customers build image for the product or service.

\section{Relate Experience}

The state of mind and the feelings of individuals are out of relate experience, but is it related to social context of the person which is bounded to any product or service. The persons having social context such as profession, language, gender and living style and social entities are based on the relate experience but the individual's cognition, sensation and feelings are not existing in relate experience. Schmitt (1999), discussed that the person's inside the social context and his/her private outside state of mind are related to relate experience. Relate marketing creates a powerful contacts and experience of customer's individual action, thought and feelings in a cultural environment and society. (Yu \& Ko, 2012).

Sukkur IBA Journal of Management and Business - SIJMB | Volume 5 No. 2 July - December 2018 ๑ Sukkur IBA University 


\section{Experiential Value}

The customer's perception about product or service either it is direct interaction on indirect observation is said to be the experiential value. Customers can create the experiential value by using product or service. (Gentile, Spiller, \& Noci, 2007). Though Wang and Lin (2010) study had concluded that there is a positive relationship between experiential marketing and experiential value and literature supports that an effective experiential marketing is able to create positive experiential value. Traditional customer value is Produced through production processes which will fulfill the traditional marketing concept effectively but recent research shows customer gets value while consuming and purchasing the Product or service (Ponsonby \& Boyle, 2004).

For customer satisfaction, the experiential value is so important. It is also important for purchase behavior and loyalty intention. Chou (2009), said that the consumers are being examined by the experiential value. It can be examined through the dimensions of experiential value like service excellence, playfulness and aesthetics. To prove unique from the competitors the company must deliver the experiential brand value to the customers. It focused on the consumer return on investment rather than delivering the traditional value service quality and price. (Zhang, Dewald, \& Neirynck, 2009).

\section{Aesthetic Appeal}

The aesthetic appeal is reaction of work performance, command of physical object and a balance proportion (Olson, 1972). There are two directions of aesthetic appeal one is entertainment and dramatic service performance and the other is visual silent environmental elements. The entertainment and service performance is achieved through the display of restaurant, whereas the attractive decoration, beautiful design and proper setting is gained through the visual elements (Holbrook, 1996).

\section{Playfulness}

The playfulness is completely intrinsic and self-oriented practice which is generated by the customers. The playfulness is the bliss and happiness that is achieved by using the product or service. The satisfaction and happiness may come from the examination of product/service (Chou, 2009). The playfulness, that specifies essential enjoyment, is the result of inherent enjoyment that results in enchanting triggers (Nigam).

\section{Service Excellence}

The service excellence is inherently a reactive response in which product or service meets the demand of customer. The marketing firm is admired by consumer for quality services because excellence in service provides a platform for its product or service to meet the customers' expectations (Keng, Huang, Zheng, \& Hsu, 2007). The consistency in service excellence in the product or service is a thankfulness job for service provider towards the customers (Holbrook, 2000).

Sukkur IBA Journal of Management and Business - SIJMB | Volume 5 No. 2 July - December 2018 @) Sukkur IBA University 


\section{Customer Return on investment}

The financial, behavioral and psychological resources that may give something in return is said to be the customer return on investment (Mathwick, Malhotra, \& Rigdon, 2001).

\section{Customer Satisfaction}

The product or service which meets the expectations of individual is known as customer satisfaction (Mittal \& Groening, 2013). All the features of product or service that satisfy customers by his implied and expressed needs is customer satisfaction (Tontini, Søilen, $\&$ Silveira, 2013). From the various relevant studies proved that the positive word and mouth, long term relationship and customer loyalty leads to the higher level of customer satisfaction (Mittal \& Frennea, 2010). The important goal for any organization is to satisfy the customers at any cost especially for tourism industry and hotel management, because there are various alternatives are available for customers at various low costs by having one alternative over another (Sandvik \& Gronhaug, 2007). If the customer is not satisfied, it means he gained experience below his expectations then customer is not happy, if he is satisfied means the experience gained according to expectations then the customer is happy. The evaluation of product or service that fulfils demand of customer is customer satisfaction, it shows the loyalty towards the product or service. The experiential value and experiential marketing are the bases to construct customer satisfaction. It will lead to satisfy when the product or service will go beyond the expectations of customer. (Choi, Wilson, \& Fowler, 2013).

\section{Theoretical Frame Work and Hypotheses}

According to above discussion, Experiential marketing leads to experiential value and customer satisfaction. The concept of experiential marketing is composed of five dimensions that are SE (Sense Experience), FE (Feel Experience), TE (Think Experience), AE (Act Experience) and RE (Relate Experience). Whereas experience value is composed of four dimensions that are AA (Aesthetic Appeal), PF (Playfulness), $S$ exc (Service Excellence) and CROI (Consumer Return on Investment). The experiential marketing is independent variable in this current study and the experiential value is the mediator and the dependent variable is the customer satisfaction, as shown in figure 1:

Sukkur IBA Journal of Management and Business - SIJMB | Volume 5 No. 2 July - December 2018 @ Sukkur IBA University 


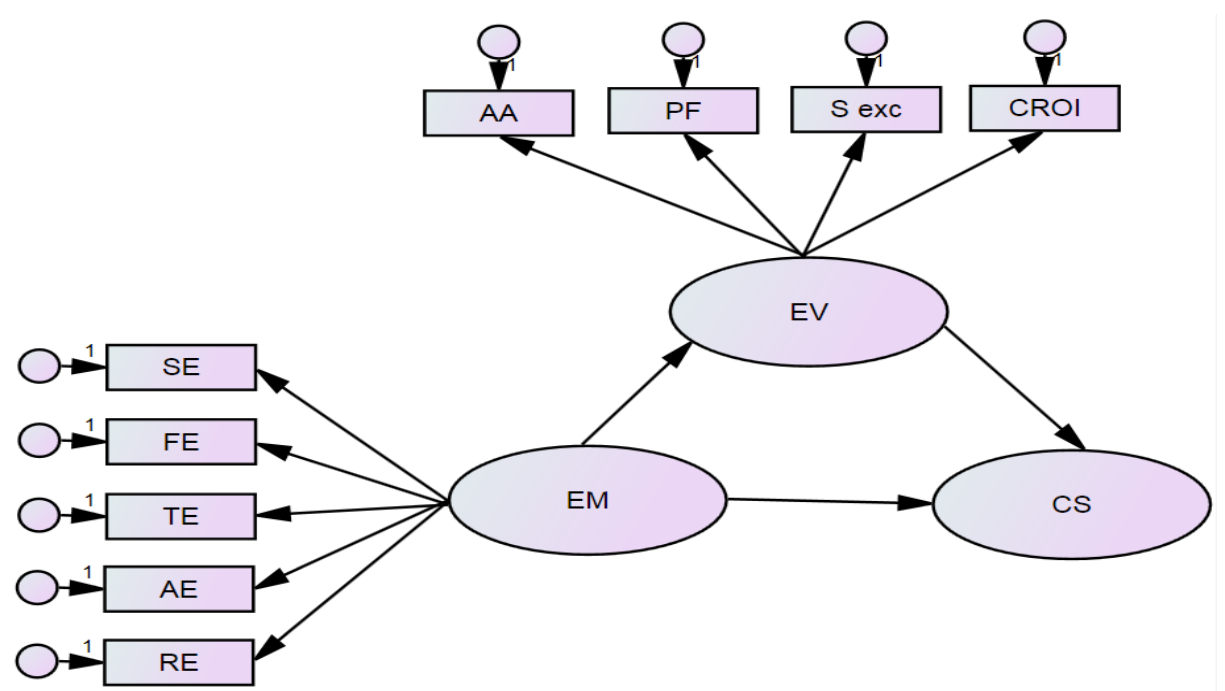

Figure 1: Experiential value mediates relationship between Experiential Marketing and Customer Satisfaction

Wang and Lin (2010), had proved that the experiential marketing has positive relationship with the experiential value. Experiential marketing leads to emotional and function value and also customer satisfaction (Schmitt, 1999). According to T. H. Lee and Chang (2012), there is a significant impact of experiential marketing on the customer satisfaction. However, Y. H. E. Yuan and C. K. Wu (2008) concluded that experiential marketing Partially stimulate customer satisfaction on the other hand M.S. Lee, Hsiao, and Yang (2010) pointed that there is a direct relationship between the experiential marketing and customer satisfaction.

On the basis of these studies we want to see the direct relationship between the experiential marketing and customer satisfaction or the indirect relationship through the experiential value. The two hypotheses were proposed on the above- based discussion.

\section{Statements of Hypotheses}

$\mathbf{H}_{1}$ : There is a direct relationship between the experiential marketing and customer satisfaction.

$\mathbf{H}_{2}$ : Experiential value mediates relationship between experiential marketing and customer satisfaction.

Sukkur IBA Journal of Management and Business - SIJMB | Volume 5 No. 2 July - December 2018 @ Sukkur IBA University 


\section{Methodology}

\section{Survey Instrument}

Adopted questionnaire consists of two parts. First parts includes different construct of measurement and second part consists of demographic profile. In first part, three variables are measured, experiential marketing is measured through survey instrument adopted and modified questionnaire of Schmitt's (1999) and assessed tools of experiential marketing; the study of experiential marketing scale, scale adopted by (Lin, Chang, Lin, Tseng, \& Lan, 2009). However, experiential value is value (mediator variable) construct was measured by (Mathwick et al., 2001) ; adopted by Lin et al. (2009), the customer satisfaction is the dependent variable which will be measured by likert scale (Czepiel, Rosenberg, \& Akerele, 1974). The questionnaire was examined by panel experts and was also tested by small group of customers to examine suitability of measurement. Respondent were suggested to point out their agreement level through likert five- point scale having value from 1 - 5 i.e. Strongly disagree to Strongly agree, as well as four demographic variables were also included in questionnaire.

\section{Data Collection}

The data were gathered by using the survey; the 200 questionnaires were randomly distributed in different business schools of four major cities of Sindh province like, Karachi, Hyderabad, Sukkur and Larkana. The sample of this current study were the students for fast food chains are present in these cities and young students used to visit fast food restaurants. The questionnaires were in English and distributed directly by researcher.

\section{Data Analysis}

The SPSS (Statistical Package for Social Sciences) V-18 and AMOS (Analysis of Movement Structure) V-18 were used to analyze the data and test the hypotheses. Hypotheses were tested by using the SEM (Structural Equation Modeling) technique, the most flexible and powerfull technique that can solve at a time all the equations and in a causal model either it consists of observed or unobserved variables (Chin, Peterson, $\&$ Brown, 2008). Second order confirmatory factors analysis used to examine model fit and mediation technique is being used to test hypothesis. Three steps were used for data analysis. In the first step data was screened and reliability and validity was checked, in second step, model fit was checked, and in third step research hypothesis were tested.

\section{Results and Discussion}

\section{Profile of Participants}

The profile of respondents' age, gender, marital status and education are shown in Table 1 as shown in table that the total number of respondents were 171 out of which 114 $(66.7 \%)$ were males and the females $57(33.3 \%)$, the age of respondents were in

Sukkur IBA Journal of Management and Business - SIJMB | Volume 5 No. 2 July - December 2018 @) Sukkur IBA University 
Irfan Ali Shah et al. Experiential value mediates relationship between Experiential Marketing and

between the 20 - to 24 -years $(62.5 \%)$, the graduates were in majority of $(37.4 \%)$ and the Post graduates $(35.7 \%)$, the respondents were students as a sample and most of the students were not married (90\%). students sample was selected because they are young and they used to visit Fast food restaurants and like Fast food more than older people in Pakistan, data is collected from Karachi which is the largest city of Pakistan as well as other cities like Hyderabad, Sukkur and Larkana are also among the major cities of Pakistan. Demographic profile of respondents is shown in table 1.

Table 1: Demographic Profile of Respondents

\begin{tabular}{lcc}
\hline & Frequency & Percentage \% \\
\hline Gender & 114 & 66.7 \\
Male & 57 & 33.3 \\
Female & & \\
Age & 16 & 9.4 \\
$16-19$ & 107 & 62.6 \\
$20-24$ & 43 & 25.1 \\
$25-30$ & 4 & 2.3 \\
$36 \&$ above & 1 & .6 \\
36 and above & & \\
Education & & 12.3 \\
Intermediate & 21 & 37.4 \\
Graduate & 64 & 35.7 \\
Master & 61 & 12.3 \\
MS & 21 & 2.3 \\
PhD & 4 & \\
Marital Status & & 90.6 \\
Single & 155 & 9.4 \\
Married & 16 & \\
\hline
\end{tabular}

\section{Reliability and Validity Analysis}

Reliability is the degree in which measurement scales are consistently measuring same results of the research, the value of Cronbach's alpha should greater than 0.7 is reliable as the indicator of scale (Tatham \& Black, 1998). Cronbach's alpha values is shown in table 2 are lowest (.70) to highest (8.25) are showing stable results, such results are shown in the table 2 . 
Irfan Ali Shah et al. Experiential value mediates relationship between Experiential Marketing and

Table 2: Reliability results of Experiential Marketing, experiential valued Customer Satisfaction

\begin{tabular}{lcc}
\hline Concept & Sub concept & Cronbach's alpha \\
\hline Experiential marketing & SE & 0.73 \\
& FE & 0.72 \\
Experiential Value & TE & 0.81 \\
& AE & 0.7 \\
& RE & 0.74 \\
Customer Satisfaction & Se exc & 0.71 \\
& PF & 0.74 \\
& AA & 0.76 \\
\hline
\end{tabular}

\section{Validity Analysis}

Convergent and discriminant validities were checked for all scales by using procedure (Hair, 2009); which recommends that convergent validity is established when average variance extracted $(\mathrm{AVE})>.50$; reliability is established when composite reliability $(\mathrm{CR})>$.70; and discriminant validity is established when maximum shared variance $(\mathrm{MSV})<$ AVE and average shared variance (ASV) < AVE (Hair, 2009). The values of experiential marketing, experiential value and customer satisfaction scale have good convergent validity and discriminant validity as shown in table 3 .

Table 3: Validity analysis

\begin{tabular}{lcccc}
\hline & CR & AVE & MSV & ASV \\
\hline Experiential Marketing & 0.9 & 0.51 & 0.39 & 0.39 \\
Experiential Value & 0.84 & 0.54 & 0.39 & 0.39 \\
Customer Satisfaction & 0.83 & 0.5 & 0.39 & 0.39 \\
\hline
\end{tabular}

\section{Measurement model results}

Measurement model focuses that how latent variables can be measured in terms of observed variable and explains measurement properties of observe variable (Diamantopoulos \& Siguaw, 2000), measurement model results were derived by applying second order confirmatory actor analysis (2nd order CFA) using Analysis of Movement Structure (AMOS) 18, by keeping all the constructs together following indices were used to asses model adequacy e.g. TLI (Tucker-Lewis Index), CFI (Comparative Fit Index), CMIN/df, and RMSEA (Root-Mean Square Error of 
Approximation). Whenever model is first time tested by (all Items and Factors ) model was the model fit statistics was poor, $(\mathrm{CMIN} / \mathrm{df}=1.626, \mathrm{CFI}=0.829 ; \mathrm{TLI}=0.816$, RMSEA $=0.06$ ), those Items having low factor loadings were removed (total 12 items were Removed) one item from sense experience, think experience, relate experience, feel experience and two items from act experience were removed respectively, however among four dimensions of experiential value one item was removed from each dimension respectively except customer return on investment due to low in factor loadings of two items of this dimensions removed. After deleting low factor loading model fit was improved significantly and reached at acceptable level in second model $(\mathrm{CMIN} / \mathrm{df}=1.499, \mathrm{CFI}=0.909 ; \mathrm{TLI}=0.901, \mathrm{RMSEA}=0.054)$. Results of full model fit are given in the table 4

Table 4: Structural Model Results

\begin{tabular}{l|ccccc}
\hline & Description & CMIN/df & TLI & CFI & RMSEA \\
\hline Model & Full conceptual model & 1.499 & 0.905 & 0.901 & 0.054
\end{tabular}

Note: TLI = Tucker-Lewis Index; CFI = Comparative Fit Index; RMSEA = Root-Mean Square Error of Approximation

The second order of confirmatory factor analysis reliability and validity results indicates that dimensions of experiential value and experiential marketing are actually measuring the experiential value and experiential marketing. For testing hypothesis, structural regression model (SR model) 0 and along 5000 bootstrapping samples were used (Preacher \& Hayes, 2008).

\section{Mediation Analysis}

Table 5: Mediation Analysis

\begin{tabular}{cccccc}
\hline & Estimates & SE & CR & p Value & Path label \\
\hline EV <--- EM & 2.1 & 0.158 & 5.601 & $* * *$ & $\mathrm{a}$ \\
CS <--- EM & 1.905 & 1.3 & 1.465 & 0.143 & $\mathrm{c}$ \\
CS <--- EV & 3.548 & 1.616 & 2.295 & 0.028 & $\mathrm{~b}$ \\
\hline
\end{tabular}

Hypothesis is tested by path analysis using Structural equation modeling (SEM) with boost strapping (5000). Boost strapping is the most famous method of testing indirect effect (Shrout \& Bolger, 2002) and Path analysis is SEM technique which emphasized on inter relation among observed variables which delivers good model-fit and estimate direct and indirect effect among the variables (Meyers, Gamst, \& Guarino, 2006), results of the study supports the hypothesis that experiential value mediates relationship between experiential marketing as shown in table 5, the standardized coefficients from EM to EV path $(\beta=2 ., \operatorname{Sig}=.000)$ and $\mathrm{EV}$ to $\mathrm{CS}$ path $(\beta=3.548$, Sig=0.028) as compare

Sukkur IBA Journal of Management and Business - SIJMB | Volume 5 No. 2 July - December 2018 @ Sukkur IBA University 
to EM to CS path $(\beta=1.9505, \mathrm{Sig}=0.143)$. standardized coefficients of path A to $\mathrm{B}$ are higher showing that indirect effect is significant as compare to $\mathrm{C}$ path and $\mathrm{P}$ value also indicates that there is full mediation because the direct effect is not significant, so the results of the study support the hypothesis (H2) that Experiential value mediates relationship between experiential marketing and Customer satisfaction and hypothesis $\mathrm{H} 1$ that is experiential marketing has direct relationship is not supported with the customer satisfaction.

\section{Conclusion and Implications}

The mediating role of experiential value is explored between the experiential marketing and customers' satisfaction in fast food restaurant of Pakistan as proposed in the theoretical model, hypothesis that is "Experiential Value mediates relationship between experiential marketing and Customer Satisfaction" is supported while hypothesis "customer experience has positive relationship with customer satisfaction" is not supported. Thus results are supporting the previous studies that experiential marketing stimulates customer satisfaction by experiential value (Y.-H. Yuan \& C. K. Wu, 2008), Experiential marketing has Positive effect on experiential value (Fulbright, Troche, Skudlarski, Gore, \& Wexler, 2001; Schmitt, 1999), experiential value has Positive relationship with Customer Satisfaction (Bolton \& Drew, 1991; Iglesias \& Guillén, 2004), The results of research support that direct effect of experiential marketing on customer satisfaction is not significant but this relationship is mediated by experiential Value.

This research concludes that decoration, delicious food, service quality and whole atmosphere is very important in building memorable customer experiences and customer perceptions. New thing in this research is that whenever company arrange an event, trade exhibition, sample testing or hand to hand demos where customer not only watches product or service but also touches or uses product or Service (Experiential Marketing) whenever customer directly or indirectly interacts with Product or Service, this interaction creates perceptions in the mind of customers (Experiential Value) and this perception will lead to customer satisfaction or dissatisfaction. This shows mediating role of experiential value. This mediating role of experiential value is rarely tested by other researchers in previous studies.

Managers should try to create valuable customer experiences and experiential values because Fast food restaurants are service -oriented businesses. Customers only can retain good experiences with themselves and these experiences will influence on customer satisfaction (Liljander \& Strandvik, 1997), bring customer loyalty(Flanagan, Johnston, \& Talbot, 2005) and sustain brands (Grace \& O'Cass, 2004). Customers nowadays buy brands due to experiential benefits instead of functional benefits (Rageh Ismail, Melewar, Lim, \& Woodside, 2011). This research will provide a new insight into marketing because now the managers of hospitality industry should not only focus on products features and attributes but also on the creating memorable experiences for

Sukkur IBA Journal of Management and Business - SIJMB | Volume 5 No. 2 July - December 2018 @ Sukkur IBA University 
the customers. Because customer experience in the modern economy is new battle field for the companies (Badgett, Boyce, \& Kleinberger, 2007). As customers visit restaurants not only for food but also for a whole dining experience like service quality, aesthetic and wonderful atmosphere. So management of fast-food restaurant should maintain service quality by providing training to its employees, management should also keep restaurant neat and clean as if customers can feel comfort.

Managers should arrange Events, Activates and Programs to create memorable experiences for customers, these memorable customer experiences will impact on the Profitability (Verhoef et al., 2009), Business performance (Prahalad \& Ramaswamy, 2004) and outcomes in marketing (e:g customer loyalty, words of mouth and customer satisfaction (Camarero, 2007). Experiential marketing also creates good brand experiences and practitioners and academicians are interested in studying, measuring and creating brand experience and recognize its worth and value in marketing strategies (Zarantonello \& Schmitt, 2010). Mangers should focus that how customer interacts employees, service escape and with other customers that are present in the restaurant because these interactions influence customer experience. At the end this research is also important in understanding the relationship between the experiential value, experiential marketing and customer satisfaction.

\section{Limitations and Future Research}

Sample size and selected sample as students have narrowed research. In order to collect the data the cross sectional design is used; to confirm the relationship over the time the longitudinal study is needed, this research has explored the positive sides of customer experience future research is needed to explore the impact of negative customer experience these variables, it needs to overcome such limitations in the future study. The researchers may conduct the study in future by selecting pure service oriented companies like financial services as well as product oriented business like automobiles and other industry to further confirm this relationship. As this research is conducted in Pakistan, it can be checked in other contexts, experiential advertising and its impact on experiential value and purchasing behavior can be another topic for future research.

Sukkur IBA Journal of Management and Business - SIJMB | Volume 5 No. 2 July - December 2018 @ Sukkur IBA University 


\section{References}

Badgett, M., Boyce, M. S., \& Kleinberger, H. (2007). Turning shoppers into advocates. IBM Institute for Business Value.

Bolton, R. N., \& Drew, J. H. (1991). A longitudinal analysis of the impact of service changes on customer attitudes. The Journal of Marketing, 1-9.

Brakus, J. J., Schmitt, B. H., \& Zarantonello, L. (2009). Brand experience: what is it? How is it measured? Does it affect loyalty? Journal of Marketing, 73(3), 52-68.

Camarero, C. (2007). Relationship orientation or service quality?: What is the trigger of performance in financial and insurance services? International Journal of Bank Marketing, 25(6), 406-426.

Chin, W. W., Peterson, R. A., \& Brown, S. P. (2008). Structural equation modeling in marketing: some practical reminders. The Journal of Marketing Theory and Practice, 16(4), 287-298.

Choi, E. K., Wilson, A., \& Fowler, D. (2013). Exploring customer experiential components and the conceptual framework of customer experience, customer satisfaction, and actual behavior. Journal of Foodservice Business Research, 16(4), 347-358. doi: 10.1080/15378020.2013.824263

Chou, H.-J. (2009). The effect of experiential and relationship marketing on customer value: a case study of international american casual dining chains in taiwan. Social Behavior \& Personality: An International Journal, 37(7).

Czepiel, J. A., Rosenberg, L. J., \& Akerele, A. (1974). Perspectives on consumer satisfaction: New York University, Graduate School of Business Administration.

Diamantopoulos, A., \& Siguaw, J. A. (2000). Introducing LISREL: A guide for the uninitiated: Sage.

Douglas, S. P., \& Craig, C. S. (2011). Convergence and divergence: developing a semiglobal marketing strategy. Journal of International Marketing, 19(1), 82-101.

Flanagan, P., Johnston, R., \& Talbot, D. (2005). Customer confidence: the development of a "pre-experience" concept. International Journal of Service Industry Management, 16(4), 373-384.

Fulbright, R. K., Troche, C. J., Skudlarski, P., Gore, J. C., \& Wexler, B. E. (2001). Functional MR imaging of regional brain activation associated with the affective experience of pain. American Journal of Roentgenology, 177(5), 1205-1210.

Gentile, C., Spiller, N., \& Noci, G. (2007). How to Sustain the Customer Experience:: An Overview of Experience Components that Co-create Value With the Customer. European Management Journal, 25(5), 395-410.

Grace, D., \& O'Cass, A. (2004). Examining service experiences and post-consumption evaluations. Journal of Services Marketing, 18(6), 450-461.

Hair, J. F. (2009). Multivariate data analysis.

Holbrook, M. B. (1996). Customer Value--A Framework For Analysis and Research. Advances in consumer research, 23(1).

Sukkur IBA Journal of Management and Business - SIJMB | Volume 5 No. 2 July - December 2018 @ Sukkur IBA University 
Holbrook, M. B. (2000). The millennial consumer in the texts of our times: Experience and entertainment. Journal of Macromarketing, 20(2), 178-192.

Iglesias, M. P., \& Guillén, M. J. Y. (2004). Perceived quality and price: their impact on the satisfaction of restaurant customers. International Journal of Contemporary Hospitality Management, 16(6), 373-379.

Ismail, A. R. (2011). Experience Marketing: An Empirical Investigation. Journal of Relationship Marketing, 10(3), 167-201. doi: 10.1080/15332667.2011.599703

Keng, C.-J., Huang, T.-L., Zheng, L.-J., \& Hsu, M. K. (2007). Modeling service encounters and customer experiential value in retailing: An empirical investigation of shopping mall customers in Taiwan. International Journal of Service Industry Management, 18(4), 349-367.

Kim, S., Cha, J., Knutson, B. J., \& Beck, J. A. (2011). Development and testing of the Consumer Experience Index (CEI). Managing Service Quality, 21(2), 112-132.

Lee, M.-S., Hsiao, H.-D., \& Yang, M.-F. (2010). The study of the relationships among experiential marketing, service quality, customer satisfaction and customer loyalty. International Journal of Organizational Innovation, 3(2).

Lee, T. H., \& Chang, Y. S. (2012). The influence of experiential marketing and activity involvement on the loyalty intentions of wine tourists in Taiwan. Leisure Studies, 31(1), 103-121. doi: 10.1080/02614367.2011.568067

Liljander, V., \& Strandvik, T. (1997). Emotions in service satisfaction. International Journal of Service Industry Management, 8(2), 148-169.

Lin, K.-M., Chang, C.-M., Lin, Z.-P., Tseng, M.-L., \& Lan, L. W. (2009). Application of Experiential Marketing Strategy to Identify Factors Affecting Guests' Leisure Behaviour in Taiwan Hot-Spring Hotel. WSEAS Transactions on Business and Economics, 6(5), 229-240.

Mathwick, C., Malhotra, N., \& Rigdon, E. (2001). Experiential value: conceptualization, measurement and application in the catalog and Internet shopping environment $\boldsymbol{z}^{2}$. Journal of retailing, 77(1), 39-56.

Meyers, L. S., Gamst, G., \& Guarino, A. J. (2006). Applied multivariate research: Design and interpretation: Sage.

Mittal, V., \& Frennea, C. (2010). Customer satisfaction: a strategic review and guidelines for managers. MSI Fast Forward Series, Marketing Science Institute, Cambridge, MA.

Mittal, V., \& Groening, C. (2013). Allocation of Resources to Customer Satisfaction and Delight Based on Utilitarian and Hedonic Benefits. Mittal, Vikas and Groening, Christopher, Allocation of Resources to Customer Satisfaction and Delight Based on Utilitarian and Hedonic Benefits (2013).

Nigam, A. Modeling Relationship between Experiential Marketing, Experiential Value and Purchase Intension in Organized Quick Service Chain Restaurants Using Structural Equation Modeling Approach.

Olson, J. C. (1972). What is an esthetic response? Paper presented at the Proceedings of the Third Annual Conference of the Association for Consumer Research.

Sukkur IBA Journal of Management and Business - SIJMB | Volume 5 No. 2 July - December 2018 @ Sukkur IBA University 
Irfan Ali Shah et al. Experiential value mediates relationship between Experiential Marketing and

Pine, B. J., \& Gilmore, J. H. (1998). Welcome to the experience economy. Harvard business review, 76, 97-105.

Ponsonby, S., \& Boyle, E. (2004). The 'Value Of Marketing' and 'The Marketing Of Value' in Contemporary Times -A Literature Review and Research Agenda. Journal of Marketing Management, 20(3-4), 343-361. doi: 10.1362/026725704323080443

Prahalad, C. K., \& Ramaswamy, V. (2004). Co-creation experiences: The next practice in value creation. Journal of interactive marketing, 18(3), 5-14.

Rageh Ismail, A., Melewar, T., Lim, L., \& Woodside, A. (2011). Customer experiences with brands: Literature review and research directions. The Marketing Review, 11(3), 205-225.

Sandvik, K., \& Gronhaug, K. (2007). How well does the firm know its customers? The moderating effect of market orientation in the hospitality industry. Tourism Economics, 13(1), 5-23.

Schmitt, B. (1999). Experiential Marketing. Journal of Marketing Management, 15(13), 53-67. doi: 10.1362/026725799784870496

Shrout, P. E., \& Bolger, N. (2002). Mediation in experimental and nonexperimental studies: new procedures and recommendations. Psychological methods, 7(4), 422.

Tatham, R. L., \& Black, W. C. (1998). Multivariate data analysis. Prcentice Hall, New Jersey. Titman, S. and R. Wessels, 1(1988), 1-19.

Tontini, G., Søilen, K. S., \& Silveira, A. (2013). How do interactions of Kano model attributes affect customer satisfaction? An analysis based on psychological foundations. Total Quality Management \& Business Excellence, 24(11-12), 12531271.

Verhoef, P. C., Lemon, K. N., Parasuraman, A., Roggeveen, A., Tsiros, M., \& Schlesinger, L. A. (2009). Customer Experience Creation: Determinants, Dynamics and Management Strategies. Journal of Retailing, 85(1), 31-41. doi: 10.1016/j.jretai.2008.11.001

Vila-López, N., \& Rodríguez-Molina, M. (2013). Event-brand transfer in an entertainment service: experiential marketing. Industrial Management \& Data Systems, 113(5), 712-731. doi: 10.1108/02635571311324160

Wang, C. Y., \& Lin, C. H. (2010). A study of the effect of tv drama on relationships among tourists'experiential marketing, experiential value and satisfaction. International Journal of organizational innovation, 2(3).

Williams, A. (2006). Tourism and hospitality marketing: fantasy, feeling and fun. International Journal of Contemporary Hospitality Management, 18(6), 482-495. doi: 10.1108/09596110610681520

Yu, H., \& Ko, H.-T. (2012). Integrating Kano model with strategic experiential modules in developing ICT-enabled services: An empirical study. Management Decision, 50(1), 7-20. doi: 10.1108/00251741211194840 
Irfan Ali Shah et al. Experiential value mediates relationship between Experiential Marketing and

Yuan, Y.-H., \& Wu, C. K. (2008). Relationships among experiential marketing, experiential value, and customer satisfaction. Journal of Hospitality \& Tourism Research, 32(3), 387-410.

Yuan, Y. H. E., \& Wu, C. K. (2008). Relationships among Experiential Marketing, Experiential Value, and Customer Satisfaction. Journal of Hospitality \& Tourism Research, 32(3), 387-410. doi: 10.1177/1096348008317392

Zarantonello, L., \& Schmitt, B. H. (2010). Using the brand experience scale to profile consumers and predict consumer behaviour. Journal of Brand Management, 17(7), $532-540$.

Zhang, J., Dewald, B., \& Neirynck, B. C. (2009). Experiential values for casino hotels in Macao. Journal of Quality Assurance in Hospitality \& Tourism, 10(2), 75-92.

Sukkur IBA Journal of Management and Business - SIJMB | Volume 5 No. 2 July - December 2018 @ Sukkur IBA University 